\title{
Crossroads of Empowerment: The Organisation of Women Domestic Workers in Brazil
}

\author{
Terezinha Gonçalves
}

\begin{abstract}
The organisation of women domestic workers in Brazil reveals a process of collective empowerment at work in a society where gender, race, and class inequalities intersect, giving rise to complex mosaics. Analysing processes of empowerment in these circumstances calls for abandoning universalising visions of women and recognising differences and inequalities beyond gender in multiracial and multicultural societies. Women domestic workers face class contradictions in establishing harmonious relationships with women bosses, who are also participants as workers in unions and other political spaces. This contradiction creates difficulties in constructing a common agenda for the advancement of domestic workers' labour rights. This article draws on participatory research with women domestic workers in the city of Salvador in north-east Brazil, and aims to analyse some of the consequences of the articulation of gender, race, and class inequalities in their lives, how these inequalities obstruct women's pathways of empowerment and what women domestic workers are doing to seek greater rights, recognition and justice.
\end{abstract}

\begin{abstract}
1 Introduction
Thinking about this article and talking with Creuza Oliveira, the ex-president of the National Federation of Domestic Workers (FENATRAD) about the trajectory of domestic workers organising in Brazil, we realised that there are many crossroads in a woman's life. These crossroads are places and moments where privilege and inequality are highlighted. Our city of Salvador is a place where Afro-Brazilian culture holds great influence. For us, crossroads are places or moments where or when you are presented with a choice or the power to make a choice. In women's lives there are other crossroads, those that often do not offer an opportunity to choose or change something in their lives, and in which their own power may be absent. At these crossroads, gender, race and social class intersections provoke an accumulation of inequalities that may make it hard to surpass the obstacles faced by women in their pursuit of pathways of empowerment.
\end{abstract}

The experience of being a woman is socially and historically constituted. There are girls who start their lives working very hard, without a chance to get a good education and choose a profession. In Brazil it is very difficult for non-white women to get a real chance to choose their destiny. Becoming a domestic worker is rarely a choice. This choice or lack of choice is the first crossroad that domestic workers face. For myself, a white middle-class woman, there were many choices when I reached that early crossroad. When I was born my family made many plans for me, including to go to a private school and become a great professional. My grandma always told me, I'll never forget: 'Never get married! Marriage is not a good business for any woman; get a good profession, be a doctor, be a lawyer, be a journalist...' In my home there were five domestic workers taking care of everything and there was one domestic worker whose only job was to take care of me. She was called 'Maria Pequena' (Little Maria), because she was only 12 years old. She carried me everywhere: to play, to the kindergarten, to bed, to be fed. She was a child taking care of another child. She did not know how to read or write. After some years she married and went back to the same poverty that had first brought her to my house. 
Greuza Oliveira, like Maria Pequena, started work when she was still a child. At the age of ten, she began looking after other children. She remembers the loneliness of being the only child in the house who received no affection, of the birthdays forgotten, of the daily humiliation of having a separate plate and cup kept under the kitchen sink, of never being able to play, or to study. She recalls: 'They called me a stinking girl, black girl with "bad hair"... Any child who grows up hearing this believes that it is the truth'. She was the same age as the family's children; she represented centuries of social inequality separating the two realities. Until the age of 15, she never received any money for her work, only food and old clothes. It was not until she was 21 that her documentation as a worker was signed for the first time. She suffered violence, from psychological violence to deferred payment and even sexual abuse. In her activism, Creuza has sought ways to put an end to successive generations of young black girls becoming domestic workers. But, she reflects: 'Exploitation is a difficult cycle to break. It passes down through generations... unfortunately, paid domestic work is a door into the work market for black women in our country'.

Through a range of interventions and alliances, Creuza and other domestic workers rights activists have brought about changes in the law, and fostered the implementation of innovative programmes that seek to change the options open to young black women at the crossroads that take them into domestic work. This article considers some of the implications of these intersections, and some of the innovations and conquests that have begun to change the situation of domestic workers in Brazil.

\section{Negotiating the 'traffic': intersections and inequalities}

Intersectional discrimination and subordination have different consequences from those arising from one form of discrimination only, whether based on race, gender, sexual orientation, age or class. The consequences of intersectional discrimination may remain unaddressed by prevailing human rights approaches, because the specific problems or conditions associated with this form of discrimination are often subsumed within one category of discrimination, such as race or gender discrimination (Pradhan-Malla 2005). Brazil's colonial past produces intersections between gender, race and class that emerge from slavery and patriarchal history. It is essential, in this context, to understand the structures that operate to produce and reproduce inequalities that block resources and access to power for those at the crossroads of the intersections of gender, race and social class.

In Brazil, racism divides white men and women and non-white men and women in different categories of income. It aggravates gender inequalities. It makes the female identity of black women inferior to that of the racially hegemonic group of white women. In the face of this inequality, it is necessary to analyse how racism subcategorises gender, creating different statuses for different women (Carneiro 2003). Black men have social indicators below those of white women in Brazil, and black women even more so (Carneiro 2003). Consequently, black women would require extraordinary social mobility to surpass both racial and gender obstacles. Despite the expansion of the labour market to include women over the last half century, the fact that 60 per cent of domestic workers are black shows that labour market expansion for women did little to improve black women's reality. When black women get a chance to get a formal education and therefore social mobility, most of them get jobs with lower salaries in poorly recognised positions in the labour market. The racial discrimination in the selection process is very clear in Brazil; 'good appearance' is a tenuous way to obstruct black people and especially black women, because having a desirable 'appearance' means being white.

Racial discrimination in the labour market is reflected in the income of black Brazilians. They have a monthly average income $50-70$ per cent less than other workers; they also make up the majority of the unemployed. Black women suffer double discrimination that results in lower wages. According to research carried out by the Institute of Applied Economic Research (IPEA), in partnership with the Special Secretary of Women's Policies (SPM) and the United Nations Development Fund for Women (UNIFEM), black women earn 67 per cent of what black men earn and 34 per cent of the average income of white men. They are at the bottom of the salary pyramid. In average wages according to race/gender in Brazil: on average white men receive US $\$ 542$ and white women receive US $\$ 338$ per month; 
black men receive US $\$ 275$ and black women receive only US\$184.

Women of colour are often positioned in the space where racism or xenophobia, class and gender meet. They and other multi-positioned groups must negotiate the 'traffic' that flows through these intersections. This is a particularly dangerous task when the traffic flows simultaneously from many directions. Injuries are sometimes sustained when the impact from one direction throws victims into the path of oncoming traffic, while on other occasions, injuries occur from fully simultaneous collisions. These are the contexts in which intersectional injuries occur - when disadvantages or conditions interact with pre-existing vulnerabilities to create a distinct dimension of disempowerment (Crenshaw 2000). A vivid example of this 'traffic flowing simultaneously' is provided by an examination of paid domestic work in Brazil. To speak of domestic workers is to speak of women at work: 95 per cent of domestic workers in Brazil are women and 60 per cent are black. Domestic workers form the largest professional category in the country: 6.8 million who work for a monthly salary, representing 5 per cent of the Brazilian population (IBGE 2007). There are 494,002 domestic workers aged 5-17 years old, 222,865 below the age of 16 (IBGE 2001; IBGE 2003). These figures probably underestimate the true scale of the problem, given that employing children under 16 is illegal.

Domestic work in Brazil is part of a pattern of economic development that is strongly influenced by the heritage of slavery, and associated with distinctive forms of gender, race and class exploitation. The legacy of slavery continues to structure the racial and sexual division of work. The exploitation that Brazilian domestic workers face has given meaning to the political organisation and action carried out by organisations of domestic workers.

In the 1920s and 30s, black women organised in the Brazilian Black Front for the first time. They argued for the recognition and status of paid domestic work, with the same rights and duties as any other work. This resulted in the creation of the first association of domestic workers in 1936, by a black communist activist called Laudelina dos Campos Melo. Domestic workers' organisation at national level began with an informal network of associations from various Brazilian states. This resulted in the creation of a National Front of Domestic Workers in 1981. This Front acquired the status of Domestic Workers National Council in 1985. In the wake of the end of 20 years of dictatorship, the political freedom to organise in the new democracy gave the movement new impetus. The National Federation of Domestic Workers (FENATRAD) was founded in 1997. In 1998, this Federation was affiliated to the National Confederation of the Workers of the Commerce and Services (CONTRACS), the Central Workers Union (CUT) and the Latin American and Caribbean Domestic Workers Confederation (CONLACTRAHO).

From the first domestic workers' association to the recent conquests of FENATRAD, domestic workers organising for rights and recognition have arrived at many crossroads and transformed them into moments of choice, and of power. The story of domestic workers' organising is one of overcoming arduous obstacles, of constructing new pathways for action and building strategic alliances. It offers rich lessons about the conquest of rights and the construction of citizenship, and about what can be done to avoid getting caught in the 'traffic'.

\section{Between women: the 'sexual re-division of work?'}

Black movement activists have succeeded in forcing the Federal Government to take measures to combat racial inequalities and racism. These actions have resulted in the recognition of the existence of institutional racism in Brazil and the implementation of affirmative action and public policies. With support from international organisations, building on the experience in the USA and UK, this programme against institutional racism brought together the black movement and women's movement to challenge racial and gender inequality in Brazil. But this crossroad also causes a deep division between women in seeking pathways for collective empowerment as women. The unjust and unequal sexual division of work puts different women on different sides. Domestic workers are on one of these sides.

The relationship between middle and upper middle-class employers and domestic workers brings the issue of class relations centre stage. This relationship of white women in the position 
of employer and black women in the position of a domestic worker reinforces racial relations of inequalities of power and resources. Women employers often disrespect domestic work as a profession - not respecting the law in terms of payment and hours. Data from the Brazilian Institute of Geography and Statistics (IBGE) shows that in Brazil there are 72 per cent of domestic workers without a Worker's Card; 27.7 per cent of them receive half of the minimum salary and 41.3 per cent receive between half of minimum salary and one minimum salary. Many maintain a relationship based on disrespectful attitudes, on the negation of rights and on keeping silence in the face of violence and sexual abuse suffered by domestic workers in the workplace at the hands of their employers, husbands, sons, friends or other relatives (Oliveira and Sant'Anna 2002). These patterns of violence have a history; as Oliveira and Sant'Anna note:

In the past we did not dare to classify the subject as being sexual abuse as today it is considered. It was only domestic-sexual violence. It was a kind of violence that forced black women to remember little had changed regarding the patterns of behaviour established between slave owners and their slaves, between the 'casa grande' and the 'senzala'.

The relationships between women employers and domestic workers are permeated by feelings and situations that confuse a working relationship. In the name of affection or friendship, many domestic workers' rights are forgotten. Creuza Oliveira reflects on how terms of endearment and talk of being 'part of the family' cloud the very real exploitation of domestic workers, noting that:

Many domestic workers live for years in the employer's home working without any rights, living an illusion of being a family member and accepting these conditions because they depend emotionally on this relationship, establishing a comfortable situation for the employers.

Most women domestic workers do not have a home of their own, they live with their employers. Their room is the smallest in the house. The furniture they use, the food they eat, the used clothes they 'inherit', the day-to-day life they live, is all attached to the family. The assertion that 'She is almost one of the family' is used to define a domestic worker's place in the world to mask their exploitation.

The domestic sphere becomes a place where the inequalities between women are reproduced. It remains a 'women's place': a place where the alliance of struggles for women's rights is broken. Confrontation in this environment is established among social classes, with a racial component; a class contradiction without men's participation, because domestic work is cast as 'women's work'. Men's place as employers - as well as employees is quite different from that of women. Men have a different status. They generally get jobs with defined tasks like gardener or driver. Normally, this kind of worker is not referred to as a 'domestic worker'. Nobody says 'I have a domestic worker who drives my car'.

Women in general continue to be responsible for reproductive, devalued and subaltern work. To escape the trap of the unjust sexual division of work, upper- and middle-class women employ other women to carry out reproductive work, and pay them for it. A false idea of autonomy is established for women who employ others: they become employers who can exploit other women, namely their domestic worker. This demonstrates only that they have freed themselves from domestic tasks and can escape from confrontation with men, who are exempt from this responsibility in the home and the family. To gain this sense they need other women as their domestic workers, who must in turn work to survive. This gives rise to tensions between women that have taken shape in recent years in organised reactions to the growing rights that domestic workers have acquired.

Domestic Employers' Unions and Housewife Associations have been created in many cities in Brazil with the purpose of organising and supporting employers' rights. This confrontation is going on in a context where the Federal Government is preparing a Proposal for Constitutional Reform (PEC) to equalise domestic workers' rights with workers' rights in general. The rights that are under discussion would represent a substantial conquest for domestic workers in their struggle for recognition as workers, and include family allowance, payment for overtime, Obligatory Guaranteed Fund for Length of Service (FGTS), unemployment benefits, insurance for work 
accidents and for Repetitive Strain Syndrome (RSS), night shift supplement, a fixed number of working hours per day, and obligatory union contribution. The Employers Union President in the state of São Paulo, Margareth Galvão Carbinato, said in one of Brazil's principal broadsheets, the Folha de São Paulo, that if all the domestic workers rights are approved in the Federal Congress, labour costs will be unsustainable for employers. She said: 'Our families are not companies; we cannot pay all the costs because domestic work is a different kind of work that doesn't generate any profit'.

At this crossroad, the organisations of domestic workers come up against this position imposed by conservative sectors of society who want to protect their privileges. The solution, Creuza Oliveira explains, has been to look for alliances:

\section{It is fundamental to establish partnerships with organisations and entities of the social movements such as the black movement, both the women and feminist movements, as well as the workers' union. The objective is to fortify the struggle of the domestic workers also incorporating the agenda of these movements, in the struggles against racism and sexism. It is necessary to make partnerships to construct a common struggle.}

\section{Women in movement: fortifying domestic workers' empowerment}

Despite the advances and the conquests achieved by the domestic workers' organisation in Brazil, this movement has been led by a small group of these workers. It is difficult to organise domestic workers. Gaining visibility for their political activism is hard. The workplace in the domestic environment often obstructs these women's participation. They have no access to information about the unions. There are also few resources from the unions to spread information about their agenda. For this reason, many domestic workers do not know their labour rights.

Women's participation in social movements union, feminist, black or grassroots movements has become a vector for significant change in the process of women's empowerment in Brazil. By acting in public, women exceed the limits of the domestic space, creating new situations inside the family, in the informal relationship of neighbourhoods, and in friendships. Women have begun to articulate differentiated struggles in relationship to men inside social movements, organising around 'women's' issues, and using this as an entry point to question their own condition and the inequalities derived from this condition. In the collective process of empowerment of women there are new practices and new representations: changes of values, new attitudes in relation to work, to the family, and better conditions in which to experience selfesteem. The conquest of women's rights implies transformations that do not only modify the daily relationships between men and women, but also has provoked significant changes in social structures and therefore in the organisation of social life. The experience of these rights as part of daily life has meant social transformations of a material and symbolic order.

Women's organising for labour rights has produced achievements that go beyond the general worker's fight for labour and social welfare laws. They illustrate the potential to transform unions into channels of expression and the fight for equality in gender and race relations. This potential is increased by the fact that institutionalised channels are spaces which are open for proposals from social movements for public policy implementation in Brazil. The performance of the National Secretariat for Women Workers (SNMT) in the national trades' union body (CUT) is an example of transformation in the union movement. What was in the past a space for labour class struggles has become a space that has given rise to active engagement in shaping policies for gender and race equality in Brazil. Since its creation the SNMT has incorporated all the main campaigns waged by women and feminists, being a vanguard, for example, in the fight to legalise abortion in Brazil. However, the political relationship between workers of different categories and domestic workers within CUT is not easy. Many domestic employers are also affiliated in the same Central Union. Women who work in banks, or teachers, or civil servants are at the same time employers of domestic workers. This relationship between workers/bosses and domestic workers in the same Central Union generates a tension in the union movement. The rights claims of domestic workers are often blocked to maintain the privileges of employers.

The old contradiction between the status of productive and reproductive work and the 
consequent lack of recognition of domestic work as work is a crossroad where every woman has to make a choice. Political alliances are unstable: 'If you don't see a light in the darkness, you must light a fire,' Creuza Oliveira says. 'Sometimes we go along with the women's movement to fight for our rights; sometimes we have to rely on the government.' This kind of strategy has been a characteristic of the history of domestic workers' organisations. During the elaboration of the Federal Constitution in 1988 after the return to democracy, a successful alliance with the feminist and the women's movement resulted in many victories for domestic workers being inscribed in the Constitution, including a right to the minimum wage, advance notice ${ }^{1}$ (30 days), one day off a week, maternity leave (120 days), paternity leave (five days) and an extra one-third of a minimum salary before taking holidays. In 2000, these rights were further extended to include the right to unemployment compensation. In 2006, domestic workers gained the right to 20 days vacation and time off for civil and religious holidays; job guarantee for pregnant women, and to not have housing, food and personal hygiene products used at the place of work deducted from their wages. In 2008, the government prohibited adolescents and children under 18 years old from doing domestic work, in line with the International Labour Organization (ILO) Convention 182 to eliminate all the worst kinds of child labour.

\section{The conquest of public policies}

Prior to the election of the Workers Party (PT) government in 2003, the state offered little support to domestic workers in the form of public policies and programmes. Since 2003, domestic workers' organisations have forged a political alliance with governmental sectors. The Workers Party (PT), which was re-elected in 2006, has proven to be a strong ally of these workers. The government has been responsive to domestic workers' demands, but it is important to point out that the legislation on paid domestic work and the conquest of public policies are a result of domestic workers' struggles organised in their unions. For this reason, the organisation of domestic workers is an example of collective empowerment in Brazil.

To give greater visibility to their cause and to strengthen their fight, domestic workers' organisations have sought to participate actively in various spaces of power and to seek representation in the legislature, as well as having a presence in a number of organisations established by the executive branch of government. FENATRAD is present in various bodies of the government as the National Council for the Promotion of Racial Equality and the National Council for the Defence of Women's Rights. These alliances with others working for gender and racial equality have become an important part of the strategy of advancing domestic workers' rights as workers, as women and as citizens.

An important achievement in the struggle for racial and gender equality in Brazil was the formal recognition by the government of gender and race inequalities, with the creation in 2003, of the Special Secretary of Women's Policies (SPM) and the Special Secretary for the Promotion of Racial Equality (SEPPIR). Both have ministry status and are linked to the Presidency of the Republic. And both have been instrumental in putting in place public policies that address the economic marginalisation and exploitation of domestic workers. SEPPIR and SPM have put domestic work as a priority in the National Policy Plans. Paid domestic work was an important item on the agenda in National, State, and Municipal Conferences of Policies for Women and Policies for Racial Equality, which took place in the years 2005 and 2007, respectively.

The government has established a permanent table for negotiations with FENATRAD to debate the problems in order to find ways to obtain rights for domestic workers. As a result the campaign, 'Rights Can Not be Less, Only More' was established. Another public policy worthy of note, implemented by the government together with FENATRAD, is the programme 'Citizen Domestic Work', a proposal made by domestic workers, which has been transformed into policy, which seeks to improve schooling together with social and professional qualifications and campaigns to improve social awareness about domestic work, with the objective of lessening the informal nature of work as well as the disrespect of domestic workers' rights. FENATRAD and the affiliated unions in the states of Bahia, Pernambuco, Sergipe, São Luiz, Rio de Janeiro and São Paulo and the public agencies: MTE, SEPPIR, SPM, the Ministry of Social Security and the Ministry of 
Education, as well as the ILO, all actively participate in this process. The validation and management of the Citizen Domestic Work Plan is carried out through meetings and workshops with the presence of grassroots leaders and workers, union representatives and FENATRAD.

\section{Pathways of collective empowerment}

All the achievements described in this article came after an intensive struggle. FENATRAD knows that there are many crossroads that the organisation faces to gain political and labour rights. My relationship with some of the domestic workers' organisation's leaders is a relationship built on political activism by the feminist and women's movements, and my work as an associate researcher in the Nucleus for Interdisciplinary Women's Studies at the Federal University of Bahia. For 28 years we have been together on this long and hard journey for the conquest of our rights as women. We fight for labour rights, against women's violence, for sexual and reproductive rights and for more political participation as well. We fight for women's citizenship.

On this journey we take our contradictions and our conflicts; we travel with our 'intersections' and consequently with our inequalities, our baggage. Many of us, like domestic workers, carry a heavy load. Paradoxically, the heaviest baggage is domestic work itself. Paid domestic work reinforces the unjust sexual division of work and also the premise that women have to be responsible for reproductive work. This 'trap' accentuates the division between women and at the same time maintains men's position of privilege. This kind of devalued work in Brazil is for non-white women. It discloses an unjust racial division of work that relegates the most insecure and precarious work to non-white people. Racism aggravates gender inequalities.

Paid domestic work does not constitute a choice for these women. Many of them start working when they are children, and when they become adults they have no chance of social mobility. Many of these women have grandmothers and mothers who work as domestic workers, revealing the perpetuation of these inequalities. Paid domestic work is the biggest issue at this crossroads of empowerment. Can we fight only for better working conditions for domestic workers or do we have to fight to change women's social position at work? I can't answer this question. But the domestic workers' organisation trajectory can teach us some lessons.

FENATRAD recognises that it is important to organise domestic workers around the fight for recognising paid domestic work as a profession, but not to forget the struggles for women's rights and the other social movements. It also recognises that the way of addressing some of the pathways of injustice that domestic workers in Brazil end up travelling is to focus on combating child domestic labour as a central strategy to stop this kind of 'destiny'. Looking back over almost a century of domestic workers' activism in Brazil, we can see that the first actions developed by the domestic workers' leadership in general were centralised into a worker's mobilisation around labour rights and social welfare. They started gathering in neighbourhoods, schools and churches. These meetings were strategies to build the organisations in each town and in different states. These groups have been extended and the struggles consolidated. In subsequent years, and in the years following Brazil's return to democratic rule and the flowering of movements in search of rights and citizenship, this was followed by other meetings, seminars and workshops at the local, regional and national level, for professional and political formation. The creation and consolidation of these associations formed the basis for creating the unions after the promulgation of the Federal Constitution in 1988, which restored to Brazilian workers the right to organise as unions. This was fundamental in giving weight to the domestic workers' struggle. The result was the creation of 45 unions in different Brazilian regions and the formation of the Domestic Workers National Council and of FENATRAD. There were also the union affiliations to national and international labour organisations, which constituted the last step in recognition and consolidation of domestic workers' organisations in Brazil.

The alliances domestic workers' organisations have made range from groups of advocacy in parliament to partnerships with international organisations, such as the ILO, UNIFEM and the United Nations Children's Fund (UNICEF) and feminist non-governmental organisations (NGOs). Other partnerships have been made with domestic workers' unions in Latin America. 
International cooperation projects have been important to obtain financial resources to develop actions for collective empowerment. Broader perspectives are exchanged in meetings with other social movements such as the national and Latin American feminist meetings, the women's national and international conferences, the racial equality national conferences and human rights conferences. Domestic workers' standpoints are now included in institutions such as the Child and Adolescent Defence Forum, the National Council of Defence of Women's Rights and the National

\section{Note}

1 This is the notice to leave employment that the domestic workers have to receive from their employers.

\section{References}

Carneiro, S. (2003) 'Women in Movement', Advanced Studies 17.49: 117-32

Crenshaw, K. (2000) 'Gender-related Aspects of Race Discrimination', background paper for Expert Meeting on Gender and Racial Discrimination, 21-24 November, Zagreb, Croatia

IBGE (2007) Contagem Da População 2007 [Population Count 2007], Rio de Janeiro: Instituto Brasileiro de Geografia e Estatistica IBGE (2003) Trabalho Infantil [Child Labour], Rio de Janeiro: Instituto Brasileiro de Geografia e Estatistica
Council of Promotion of Racial Equality and in many other states and city councils where public policies are discussed and monitored.

The movement for empowerment of women traces a history, a collective history made by many anonymous hands and minds. Finally, we can conclude that there is no possibility of individual empowerment for a woman domestic worker without social organisation. Collective action is the pathway to choose at the crossroads for women's empowerment.
IBGE (2001) Pesquisa Nacional por Amostra de Domicílios [National Research by Sample of Residences], Rio de Janeiro: Instituto Brasileiro de Geografia e Estatistica

Oliveira, Guacira and Sant'Anna, W. (2002) 'No More Nostalgia. The Reality is That...', Feminist Studies Revue 1: 201-07

Pradhan-Malla, S. (2005) 'Racism and Gender', in Dimensions of Racism, proceedings of a workshop to commemorate the end of the United Nations Third Decade to Combat Racism and Racial Discrimination, New York and Geneva: UN 